\title{
MONITORING LEAF AREA INDEX AT WATERSHED LEVEL THROUGH NDVI FROM LANDSAT-7/ETM+ DATA
}

\author{
Alexandre Cândido Xavier ${ }^{1}$; Carlos Alberto Vettorazzi²* \\ ${ }^{1}$ Instituto Nacional de Pesquisas Espaciais - Divisão de Sensoriamento Remoto, Av. dos Astronautas, 1758 - \\ 12227-010 - São José dos Campos, SP - Brasil. \\ ${ }^{2}$ USP/ESALQ - Depto. de Engenharia Rural, C.P. 09 - 13418-900 - Piracicaba, SP - Brasil. \\ *Corresponding author <cavettor@esalq.usp.br>
}

\begin{abstract}
Leaf area index (LAI) is an important parameter of the vegetation canopy, and is used, for instance, to estimate evapotranspiration, an important component of the hydrological cycle. This work analyzed the relationship between LAI, measured in field, and NDVI from four dates (derived from Landsat-7/ETM+ data), and with such vegetation index, to generate and analyze LAI maps of the study area for the diverse dates. LAI data were collected monthly in the field with LAI-2000 equipment in stands of sugar cane, pasture, corn, eucalypt, and riparian forest. The relationships between LAI and NDVI were adjusted by a potential model; $57 \%$ to $72 \%$ of the NDVI variance were explained by the LAI. LAI maps generated by empirical relationships between LAI and NDVI showed reasonable precision (standard error of LAI estimate ranged from 0.42 to $0.87 \mathrm{~m}^{2} \mathrm{~m}^{-2}$ ). The mean LAI value of each monthly LAI map was shown to be related to the total precipitation in the three previous months.
\end{abstract}

Key words: biophysical variable, remote sensing, spectral vegetation indices

\section{MONITORAMENTO DO ÍNDICE DE ÁREA FOLIAR EM NÍVEL DE BACIA HIDROGRÁFICA POR MEIO DO NDVI DERIVADO DE IMAGENS LANDSAT-7/ETM+}

\begin{abstract}
RESUMO: O Índice de Área Foliar (IAF) é um importante parâmetro do dossel da vegetação, sendo utilizado, por exemplo, para estimar a evapotranspiração, um importante componente do ciclo hidrológico. Analisouse a relação entre o IAF, medido em campo, e o índice de vegetação NDVI, de quatro datas (a partir de dados Landsat-7/ETM+) e, com este índice, foram gerados e analisados mapas de IAF da área de estudo para as diferentes datas. O IAF foi coletado mensalmente em campo, com o equipamento LAI-2000, em áreas de cana-de-açúcar, pastagem, milho, eucalipto e floresta ripária. A relação entre o IAF e o NDVI foi melhor ajustada por um modelo potencial, sendo que de $57 \%$ a $72 \%$ da variação do NDVI puderam ser explicados pelo IAF. Os mapas de IAF gerados por modelos empíricos da relação entre o IAF e NDVI mostraram razoável precisão (o erro padrão da estimativa de IAF variou de 0,42 a $0,87 \mathrm{~m}^{2} \mathrm{~m}^{-2}$ ). O valor médio de IAF para cada mapa mensal mostrou-se relacionado com a precipitação total dos três meses anteriores.

Palavras-chave: variável biofísica, sensoriamento remoto, índices espectrais de vegetação
\end{abstract}

\section{INTRODUCTION}

Early studies have drawn the attention of the world community to the lack of clean water in some regions and its increasing demand for the next years. Vörösmarty et al. (2000) concluded that global-scale changes in population and economic development in the next years will dictate the future water supply and demand to a much greater degree than will changes in mean climate. Currently, one billion people lack access to clean water and almost three billion people are devoid of sanitation services (Jackson et al., 2001). Therefore, studies concerning the hydrological cycle on a basin scale may help a better understanding of the relation that human changes can cause to water circulation and distribution, assisting managers to take better decisions to minimize damages to the environment and improving the use of water.

One important component of the hydrological cycle is evapotranspiration. For instance, approximately $70 \%$ of the total water precipitation on continental United States, is believed to return to the atmosphere by evapotranspiration (Rosenberg et al., 1983). The Leaf Area Index (LAI) is one of the most important biophysical variables for estimating evapotranspiration (Sellers et al., 1997). At regional scales, LAI can only be estimated by remote sensing data. Running et al. (1989), for example, mapped regional forest evapotranspiration, where LAI, which was used in the model as one canopy parameter, was estimated through remote sensing data.

Spectral Vegetation Indices (SVIs) are techniques usually used to analyze canopy properties from remote 
sensing data. The most common SVI is the Normalized Difference Vegetation Index (NDVI), computed as NDVI $=(\mathrm{NIR}-\mathrm{RED}) /(\mathrm{NIR}+\mathrm{RED})$, where: RED is the reflectance in the red wavelength; and NIR is the reflectance in the near-infrared wavelength. Several studies have related NDVI to: LAI (Green et al., 1997; Turner et al., 1999); biomass (Tucker, 1979); fraction of absorbed photosynthetically active radiation (Asrar et al., 1984); and fraction of green vegetation (Purevdorj et al., 1998). However, NDVI is affected by a combination of canopy structure and source-sensor geometry (Goetz, 1997). For example, usually NDVI increases as Solar Zenith Angle (SZA) increases (Middleton, 1991; Deering et al., 1999). Dependence of NDVI on canopy structure can be observed in the study of Spanner et al. (1990), and dependence on soil brightness, in Huete (1988). For these reasons, accurate estimating LAI continually in time is a hard task, since remote sensing data are generally acquired under diverse sun-sensor geometry and soil brightness.

This work analyzed the relationship between LAI, measured in the field, and NDVI from four dates (derived from Landsat-7/ETM+ data), and with such SVI, generated and analyzed LAI maps of the study area for the diverse dates.

\section{MATERIAL AND METHODS}

\section{Study area}

The study area was the Ribeirão dos Marins watershed, an area of 5,973 ha $\left(47^{\circ} 42^{\prime} \mathrm{S}, 22^{\circ} 47 \mathrm{~W}\right)$, in Piracicaba, State of São Paulo, Brazil. According to the Köppen classification system, the climate is Cwa, humid subtropical, with rainy summer and dry winter. The average annual precipitation is $1,278 \mathrm{~mm}$, with monthly average temperatures varying from $24.9^{\circ} \mathrm{C}$ in the summer to $17.1^{\circ} \mathrm{C}$ in the winter, with annual average of $21.4^{\circ} \mathrm{C}$ (Sentelhas et al., 1998). The main soil types in the study area are Rhodic Eutrudox, Rhodic Hapludox, Xanthoc, Lithic Udorthents, and Kandiudalfic Eutrudox (Oliveira, 1999). The study area is covered mainly by sugar cane and pasture, and presents remnants of riparian forests, eucalypt plantations, and small areas of annual crops and vegetables.

\section{Field measurements}

Between the $15^{\text {th }}$ and the $20^{\text {th }}$ days of each month of 2001, 41 stands were visited in the watershed. When the stand presented some vegetation, LAI was measured with a LAI-2000 Plant Canopy Analyzer (LI-COR Inc., 1992). The number of replications for each land cover type was defined by LI-COR Inc. (1992) methodology, being established 10 replications for each stand of forest types (eucalypt and riparian forest), and 16 replications for each stand of non-forest types (sugar cane, corn, and pasture). Replications within each stand were separated at least $5 \mathrm{~m}$. For accurate location of each stand, a handheld GPS receiver was used.

\section{Remote sensing data}

Four Landsat/ETM+ images (path 220 / row 76) were acquired to analyze the relationship LAI-NDVI and to generate LAI maps of the study area. They were separated in time by two to five months (01/18/2001, 03/23/ 2001, 08/14/2001, and 11/02/2001). The images were registered to an existing geo-rectified image (UTM/SAD69 datum) using the nearest-neighbor method. The root mean square error for all images was approximately 0.5 pixel. The RED and NIR surface reflectance were calculated using the 6S model (Vermote et al., 1997). The input parameters of the $6 \mathrm{~S}$ model used were its standard atmospheric model (tropical atmospheric model) and its aerosol model (continental model). For each of the stands where LAI was measured in the field, the average value for a $2 \times 2$ or $3 \times 3$ pixel window of RED and NIR was collected to calculate its respective NDVI, according to the shape and size of the stand.

\section{Relationship between RED, NIR, and NDVI}

In this work, NDVI was used because in a previous analysis with data from the month of January only, Xavier \& Vettorazzi (2004) found that NDVI was better correlated with LAI, when it was compared with the SVIs Simple Ratio (SR=NIR/RED; Jordan, 1969) and Soil Adjusted Vegetation Index (SAVI= 1.5(NIR-RED) I (NIR+RED+0.5); Huete, 1988). Linear (Chen \& Cihlar, 1996; Fassnacht et al., 1997) and potential (Peterson et al., 1987) models, with LAI as independent variable, were used to analyze the relationships between LAI and NDVI, as well as the relationship between LAI and the individual ETM+ bands. Quadratic and cubic models were not used, since such behavior between LAI and dependent data (RED, NIR and NDVI) was not observed in the previous analysis. A residual analysis was used to identify model violations. The coefficient of determination $\left(\mathrm{R}^{2}\right)$, the standard error (se), and the observed significance level $(P)$ were considered in the models analysis.

\section{Predicting LAI and its mapping}

The models LAI-NDVI for each date to predict LAI were evaluated according to Gong et al. (1995) methodology. LAI and NDVI were the dependent and the independent variables, respectively. For each date, the samples were split into two groups, predicting and testing. The predicting group was used in the coefficient estimation to establish the prediction equations, while the test group was used to calculate se. Separation between samples of each group was made randomly. Finally, the prediction equations for each date were applied to their respective NDVI image to generate LAI maps. 


\section{RESULTS AND DISCUSSION}

During 2001 field campaign, the average temperature was $22.5^{\circ} \mathrm{C}$ with a mean maximum of $26.0^{\circ} \mathrm{C}$ and a mean minimum of $18.5^{\circ} \mathrm{C}$, in February and June, respectively. The total precipitation was $1,372 \mathrm{~mm}$ (Figure 1; DAEE, 2002), the accumulated precipitation from April to September was only $18 \%$ of total precipitation for the year. The correlation between mean temperature and precipitation during 2001 was high (0.84).

In the field campaign, LAI was collected in stands of sugar cane, pasture, corn, eucalypt, and riparian forest. LAI ranged from 0.16 to 4.90 (sugar cane and riparian forest, respectively). However, the maximum LAI observed in the months in which images were acquired was 4.51 (remnant of riparian forest, November). Table 1 summarizes the results of LAI field campaign for the months in which images were acquired. A complete analysis of LAI data can be seen in Xavier \& Vettorazzi (2003).

Figure 2 shows box-plots of LAI data for the months in which images were acquired. Except for August, LAI ranges were similar. The lower LAI values collected in August were a result of the meteorological conditions, with lower precipitation and temperature, as well as the great amount of sugar cane data, being that in such period, most of these stands were in the initial stage of development.

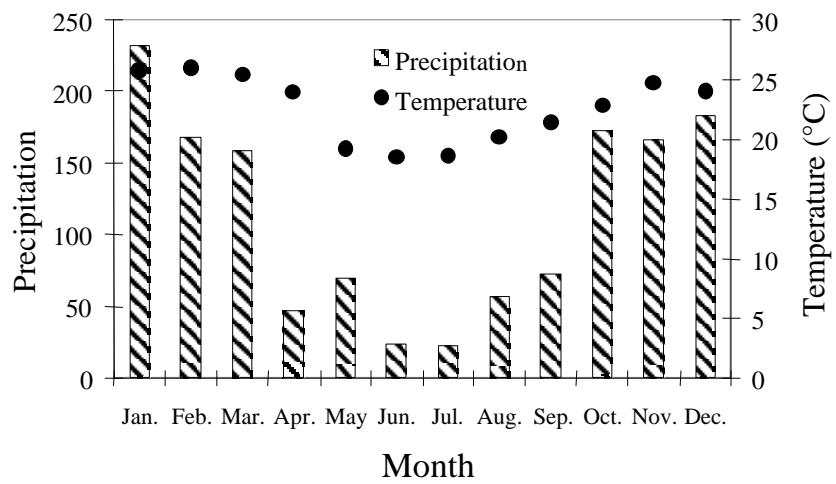

Figure 1 - Precipitation and mean monthly temperature during 2001 of Ribeirão dos Marins watershed.

\section{Relationship between LAI and individual bands (RED and NIR)}

The relationship between LAI and RED is characterized by radiation absorption in the red wavelength by pigments in leaves, while the relationship between LAI and NIR is characterized by multiple scattering of radiation in near-infrared wavelength by the leaves (Gates et al., 1965). Consequently, a negative relationship between LAI and RED is expected. As LAI increases, a larger leaf area will absorb more red radiation, therefore reflecting less this wavelength. The LAINIR relationship would be positive due to an increase of the multiple scattering of the radiation in this wavelength as leaf area increases. The variations of RED and NIR depend, besides LAI, on other factors, like: i) canopy structure (e.g. closure, leaf angle distribution, plant height etc.) (Asrar et al., 1985; Myneni et al., 1997); ii) target and source-sensor geometry (Middleton, 1991; Walter-Shea et al., 1997; Deering et al., 1999); iii) background brightness (Huete, 1988).

The relationships between LAI and RED, evaluated separately in each of the four months, were significant $(P<0.01)$. The empirical models that best fit these relationships for all months were linear negative (Figure 3$)$. The coefficient of determination $\left(R^{2}\right)$ ranged from 0.50 to 0.68 (Table 2). The magnitudes of $R^{2}$ found in this work were consistent with those found in other studies: Holben et al. (1980), $\mathrm{R}^{2}=0.57$ for soybean; Peterson

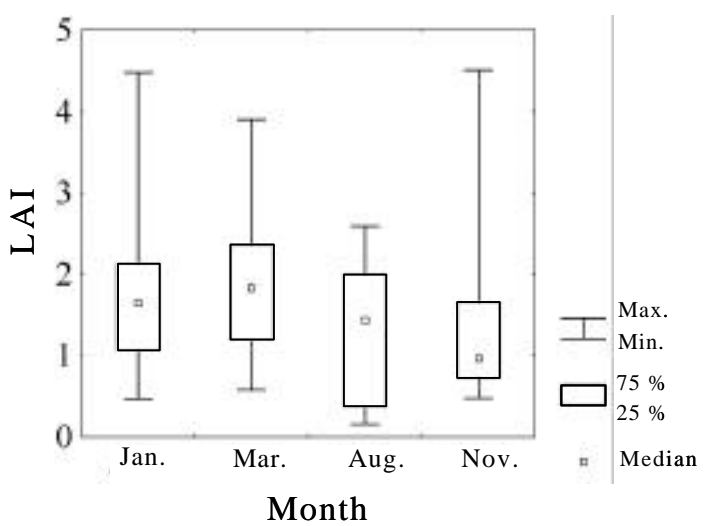

Figure 2 - Box-plots of Leaf Area Index (LAI) field campaign data for January, March, August, and November.

Table 1 - Number of stands in the months in which images were acquired, per land cover type. In parentheses, minimum and maximum Leaf Area Index (LAI) values.

\begin{tabular}{lcccr}
\hline & \multicolumn{4}{c}{ Summarized results of field campaign when images were acquired } \\
\cline { 2 - 5 } Land cover & January & March & August & \multicolumn{1}{c}{ November } \\
\hline Sugar cane & $22(0.47 ; 2.37)$ & $23(0.58 ; 2.39)$ & $24(0.16 ; 2.53)$ & $23(0.48 ; 2.60)$ \\
Corn & $2(1.26 ; 1.86)$ & - & - & $2(1.61 ; 2.16)$ \\
Pasture & $3(1.09 ; 2.03)$ & $3(2.06 ; 2.45)$ & $1(0.85)$ & $4(0.72 ; 1.64)$ \\
Eucalypt & $3(1.99 ; 3.11)$ & $3(2.07 ; 3.13)$ & $3(2.00 ; 2.52)$ & $3(1.66 ; 2.45)$ \\
Riparian forest & $2(3.21 ; 4.48)$ & $2(2.89 ; 3.90)$ & $2(1.96 ; 2.59)$ & $2(2.93 ; 4.51)$ \\
\hline Total & $32(0.47 ; 4.48)$ & $31(0.58 ; 3.90)$ & $30(0.16 ; 2.59)$ & $34(0.48 ; 4.51)$ \\
\hline
\end{tabular}

Sci. Agric. (Piracicaba, Braz.), v.61, n.3, p.243-252, May/June 2004 
Table 2 - Models for the relationships between Leaf Area Index (LAI) and Red Reflectance (RED).

\begin{tabular}{llclccc}
\hline Date & $\mathrm{SZA}^{1}$ & Models & $\mathrm{N}$ & $\mathrm{R}^{2}$ & $\mathrm{P}$ & se \\
\hline January & $32.7^{\circ}$ & $\mathrm{RED}=-0.017 \mathrm{LAI}+0.080$ & 32 & 0.64 & $<0.01$ & 0.01 \\
March & $41.1^{\circ}$ & $\mathrm{RED}=-0.015 \mathrm{LAI}+0.067$ & 31 & 0.53 & $<0.01$ & 0.01 \\
August & $49.7^{\circ}$ & $\mathrm{RED}=-0.038 \mathrm{LAI}+0.137$ & 30 & 0.68 & $<0.01$ & 0.02 \\
November & $28.2^{\circ}$ & $\mathrm{RED}=-0.031 \mathrm{LAI}+0.140$ & 34 & 0.50 & $<0.01$ & 0.03 \\
\hline
\end{tabular}

${ }^{1}$ Solar Zenith Angle

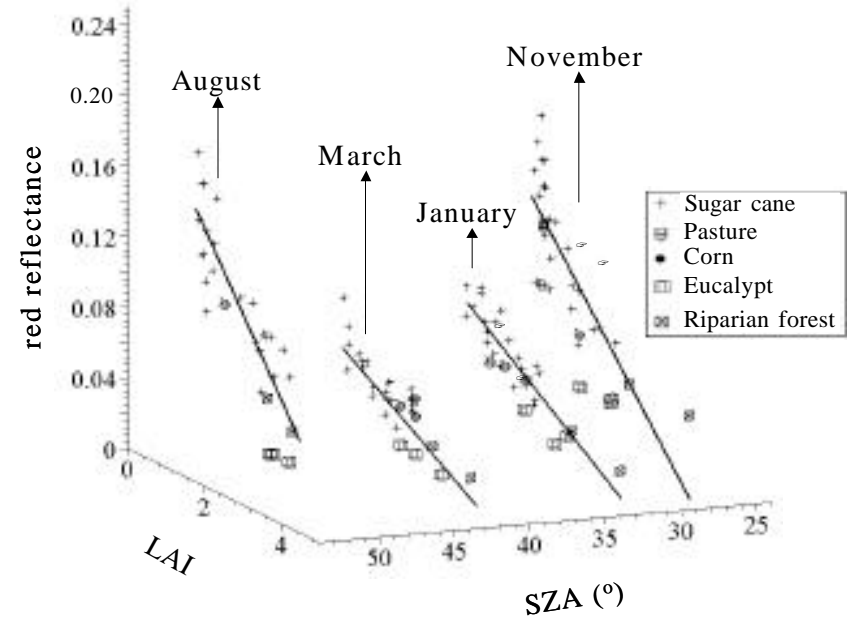

Figure 3 - Scatter diagram between Leaf Area Index (LAI), Solar Zenith Angle (SZA), and Red Reflectance (RED) for January, March, August, and November.

et al. (1987), $R^{2}=0.89$ for forest; Spanner et al. (1990), $\mathrm{R}^{2}=0.80$ for forest; and Gong et al. (1995), $\mathrm{R}^{2}=0.72$ for forest.

Eucalypt data generally presented lower RED values than other land cover types for the same LAI range. This behavior might be associated with the amount of shadow of this land cover resulting from its canopy structure. Eucalypt plantations in the study area were in the adult stage, planted in rows spaced $3 \mathrm{~m}$, showing several gaps in the canopy, thus increasing the shadow amount and, consequently, decreasing RED values. Riparian forest did not present such behavior. In the field, differently of eucalypt, riparian forest did not present so many gaps in its canopy. Certainly the color of the leaves and the pigments, for instance, had influenced the RED response. Future radiometric studies may help to better understand and analyze this result.

LAI-RED regressions for January and March and for August and November presented equal intercepts and slopes $(P=0.05)$. Two of the possible sources that may justify RED variation in similar levels of LAI in the distinct dates are the respective SZA and the background conditions for each date, since it was considered in this work that atmospheric effects were adequately corrected for all dates. Some examples of observed SZA-RED behavior can be cited: i) RED reduction as SZA increased, in wheat (Jackson et al., 1979); ii) Middleton (1991) ob- served diverse behaviors in this relationship in tallgrass prairie, but the most frequent behavior was also RED reduction as SZA increased; iii) nearly linear RED decrease as SZA increased for black spruce and jack pine, as a result of darker shadows for greater SZA; and for aspen, the relationship between SZA and RED was nearly constant due to the lack of strong differences in reflectance between sunlit and shadowed understory hazelnut canopy (Deering et al., 1999).

For a given LAI value, RED frequently decreased as SZA increased or, at least, RED values were constant for SZA variations, as seen regarding November's RED response in this work, which presented the lower SZA $\left(28.2^{\circ}\right)$ and higher or equivalent RED values for the same LAI range compared with the other months (Figure 3). However, RED values for August $\left(\mathrm{SZA}=49.7^{\circ}\right)$ had an opposite SZA-RED behavior, since for this date RED values were greater than those observed in January and March, with lower SZA, $32.7^{\circ}$ and $41.1^{\circ}$, respectively. This result might be associated with higher background brightness as a result of the lack of rainfall in August, which caused greater RED values than those observed for January and August.

RED values for eucalypt seem to be less affected by SZA and background. A pattern of low values for all dates, possibly due to the high amount of shadows for diverse SZAs, may have constrained the influence that background brightness could have on the spectral response of this land cover.

General correlation between LAI and NIR for the distinct dates was not observed $(P>0.05)$. For this relationship, no correlations were also observed in forest areas (Peterson et al., 1987; Spanner et al., 1990). Peterson et al. (1987) found that no significant relationship between LAI and NIR occurred as a result of variation in canopy closure, understory vegetation, and background reflectance. In this work, when only non-forest stands were considered, the relationship LAI-NIR became significant $(P<0.05)$ for January and March, although with low $\mathrm{R}^{2}$ ( 0.36 and 0.26 , respectively), and that means that the canopy structure influenced NIR response for the studied land covers, as observed in other studies.

The average values of NIR in the stands where LAI were collected, for January, March, August, and November, were $0.34^{\mathrm{a}}, 0.29^{\mathrm{b}}, 0.25^{\mathrm{c}}, 0.32^{\mathrm{ab}}$ (values followed 
by same letters do not differ at 5\%), respectively. The NIR response was only dependent on SZA, which could explain only $35 \%$ of the NIR variance; NIR decreased at the rate of 0.0036 per degree of SZA increase (Figure 4). Distinct behaviors in the relationship SZA-NIR were observed in other studies. Studying tallgrass prairie, Middleton (1991) observed that generally NIR decreased with increasing SZA, when green biomass was high, and canopies with low green biomass presented constant low NIR values for diverse SZA. Deering et al. (1999) observed: i) for black spruce, NIR decreased as SZA increased, as a result of dense upper canopy architecture; ii) for jack pine, constant NIR for diverse SZA; and iii) for aspen, NIR tended to increase as SZA increased. For a better understanding of the results, it would be necessary running an in situ radiometric field campaign where reflectance data would be collected under diverse SZA and soil brightness for the studied land cover types.

Apparently, eucalypt NIR values as well as RED values, for distinct dates, were lower than NIR values of other land-cover types for similar LAI. Again, this fact can be the result of higher amount of shadow in the eucalypt plantation.

\section{Relationship LAI-NDVI}

The relationship between LAI and NDVI revealed similar patterns for the four dates (Figure 5). Potential model gave the best fit for LAI-NDVI relationships, where $\mathrm{R}^{2}$ were not different $(P<0.05)$, ranging from 0.57 (November data) to 0.72 (January data), equivalent to the magnitude of $\mathrm{R}^{2}$ observed in other studies under varied land-cover types (Peterson et al., 1987; Spanner et al., 1990; Fassnacht et al., 1997; Green et al., 1997; Turner et al., 1999). The se ranged from 0.06 to 0.12 (Table 3 ).

The NDVI is dependent on RED and NIR response of the target, since NDVI $=f(\mathrm{RED}, \mathrm{NIR})$, and reflectance in these individual bands are the result of the interaction between target and sensor-source geometry. For instance, changes on SZA for the same target can cause variations in NDVI values because, at first, single bands are affected in distinct manners (Middleton, 1991; Deering et al., 1999). Epiphanio \& Huete (1995) have already determined the dependence of NDVI on the individual bands. In this work, this relationship was evaluated for the RED and NIR range of values found for the diverse land cover types in the studied area. Figure 6 shows the gradient vector field of NDVI, where vectors

Table 3 - Leaf Area Index (LAI)-Normalized Difference Vegetation Index (NDVI) models for the four dates.

\begin{tabular}{lllllcc}
\hline Date & $\mathrm{SZA}^{1}$ & Models & $\mathrm{N}$ & $\mathrm{R}^{2}$ & $\mathrm{P}$ & se \\
\hline January & $32.7^{\circ}$ & $\mathrm{NDVI}=0.687 \mathrm{LAI}^{0.181}$ & 32 & 0.72 & $<0.01$ & $<0.06$ \\
March & $41.1^{\circ}$ & $\mathrm{NDVI}=0.685 \mathrm{LAI}^{0.200}$ & 31 & 0.62 & 0.06 \\
August & $49.7^{\circ}$ & $\mathrm{NDVI}=0.486 \mathrm{LAI}^{0.343}$ & 30 & 0.71 & $<0.01$ & 0.12 \\
November & $28.2^{\circ}$ & $\mathrm{NDVI}=0.496 \mathrm{LAI}^{0.347}$ & 34 & 0.57 & $<0.01$ & 0.09 \\
\hline
\end{tabular}

${ }^{1}$ Solar Zenith Angle

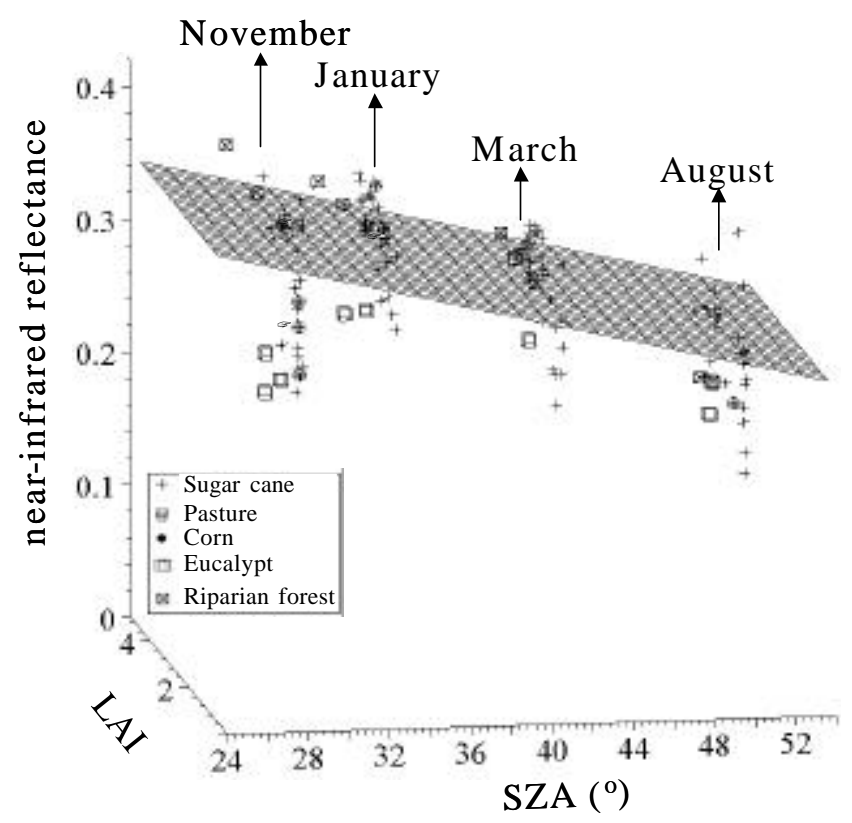

Figure 4 - Scatter diagram between Leaf Area Index (LAI), Solar Zenith Angle (SZA), and Near-infrared Reflectance (NIR) for January, March, August, and November (NIR $\left.=0.4381-0.0036 \mathrm{SZA} ; \mathrm{R}^{2}=0.35 ; s e=0.04 ; P<0.01\right)$.

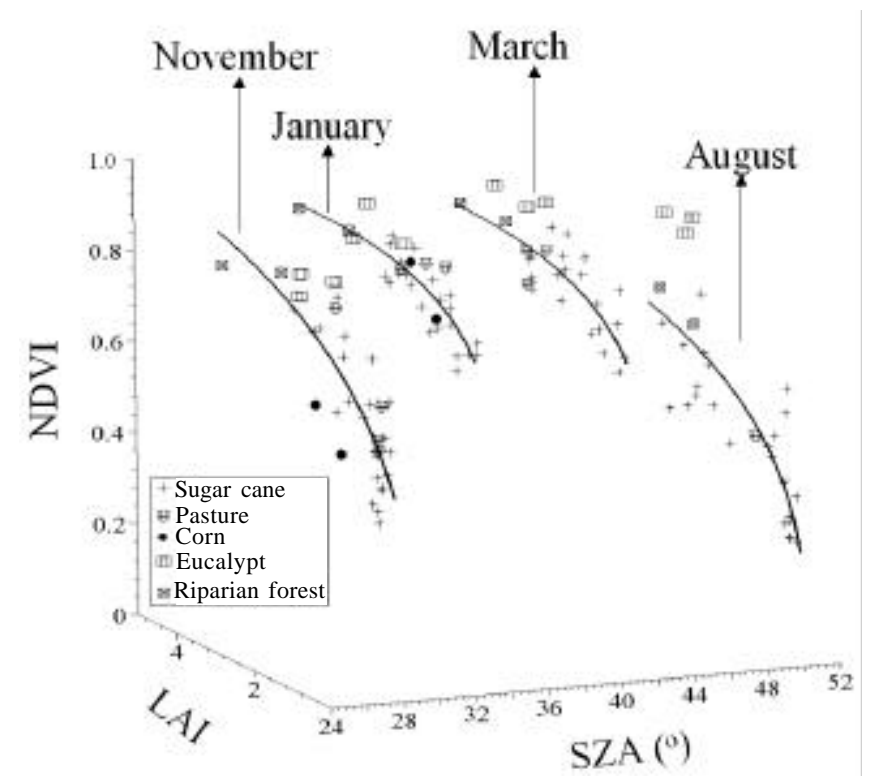

Figure 5 - Scatter diagram between Leaf Area Index (LAI), Solar Zenith Angle (SZA), and Normalized Difference Vegetation Index (NDVI) for January, March, August, and November. 
give the direction of the fastest increase of NDVI. The dominant variable in the rate change of NDVI is RED, except when RED presents high values (RED>0.15). Therefore, the NDVI increases or decreases faster when RED values are small, generally independently of NIR values.

The NDVI behavior shown in Figure 6 explains why January and March NDVI values were greater than those values of August and November (Figure 5). This occurred mainly because of the lower RED values observed for these months (Figure 3), resulting in greater NDVI values. It also explains the generally greater eucalypt NDVI values compared with other land cover types' NDVI values, as is clearly observed for August eucalypt NDVI values. Generally, eucalypt RED values were lower than other land covers' RED (Figure 3), resulting in greater NDVI values for eucalypt when compared to the NDVI values of the other land covers.

NDVI saturation was not observed for LAI values measured in this work. This result is consistent with other works. Gong et al. (1995), Spanner et al. (1990), and Turner et al. (1999) observed that saturation would occur for LAI values approximately greater than 5.00.

\section{LAI mapping and analyses}

Generation of LAI maps by the relationships between LAI and SVIs have been done with some success. Recently, Chen et al. (2002) used relationships between LAI of distinct land cover types and the SVI Simple Ratio (NIR/RED) from NOAA/AVHRR data to generate a

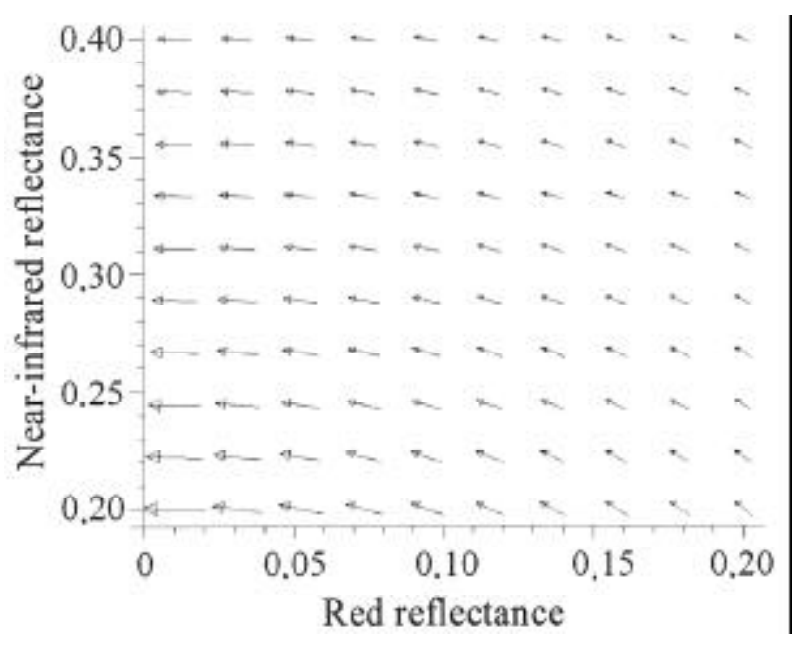

Figure 6 - Gradient vector field of NDVI, that is, $\nabla N D V I=\frac{\partial N D V I}{\partial \operatorname{red}} \mathbf{i}+\frac{\partial N D V I}{\partial n I R} \mathbf{j}$.
Canada-wide LAI map. In this work, the models used to generate LAI maps, for the respective months, were evaluated according to the methodology presented by Gong et al. (1995). The predicted group consisted of 22, 21, 20, and 24 samples for January, March, August, and November, respectively, while the test groups were represented by other 10 samples for each date.

The NDVI explained $54 \%$ to $74 \%$ (November and January, respectively) of the variance in LAI by means of the potential models (Table 4). The se of LAI in the test groups ranged from 0.42 to 0.87 (August and November, respectively) showing reasonable precision in the LAI estimate (Figure 7). For August, the highest se test group value was related to eucalypt data, which presented greater NDVI value, biasing the model. In future studies, data stratification could improve the result. Data stratification was not used in this work since the eucalypt area was small in the watershed, and a greater number of eucalypt data would be needed to generate an exclusive model for eucalypt.

Models in Table 4 were applied to their respective NDVI images to generated LAI maps (Figure 8). Light tones in Figure 8 correspond to areas of eucalypt and riparian forests; medium gray tones generally correspond to sugar cane or pasture areas; the dark tones are equivalent to bare soils or areas with minimal green vegetation.

Table 5 provides the descriptive statistics of predicted LAI in the watershed for each month. Variations of the mean LAI observed among the months were driven by precipitation, which increases LAI values. The mean LAI values for August were lower than those values for the other months, because sugar cane plantations, which covered most of the area, were in the initial stage of development; in the other months, sugar cane LAI were higher as a result of its advanced stage of development.

August presented the larger area with lower LAI values due to, as already observed, low precipitation in the previous months, and extensive area of sugar cane in the initial phases of development (Figure 9). August presented approximately $88 \%$ of the area with LAI lower than 1.80 , while for the remaining months, the area with LAI values below 1.80 was always smaller (up to $63 \%$ ). In January and March the areas of LAI classes were similar, also presenting equal means (LAI=1.59). This result might be associated with the high and similar precipitations and temperatures in these months, as well as, for

Table 4 - Models for Leaf Area Index (LAI) estimation.

\begin{tabular}{llclccc}
\hline Month & SZA $^{1}$ & Models & $\mathrm{N}$ & $\mathrm{R}^{2}$ & $\mathrm{P}$ & se \\
\hline January & $32.7^{\circ}$ & LAI $=4.546 \mathrm{NDVI}^{3.496}$ & 22 & 0.74 & $<0.01$ & 0.38 \\
March & $41.1^{\circ}$ & $\mathrm{LAI}=4.486 \mathrm{NDVI}^{3.616}$ & 21 & 0.59 & $<0.01$ & 0.57 \\
August & $49.7^{\circ}$ & $\mathrm{LAI}=4.190 \mathrm{NDVI}^{2.138}$ & 20 & 0.72 & $<0.01$ & 0.57 \\
November & $28.2^{\circ}$ & $\mathrm{LAI}=3.682 \mathrm{NDVI}^{1.781}$ & 24 & 0.54 & $<0.01$ & 0.67 \\
\hline
\end{tabular}

${ }^{1}$ Solar Zenith Angle 

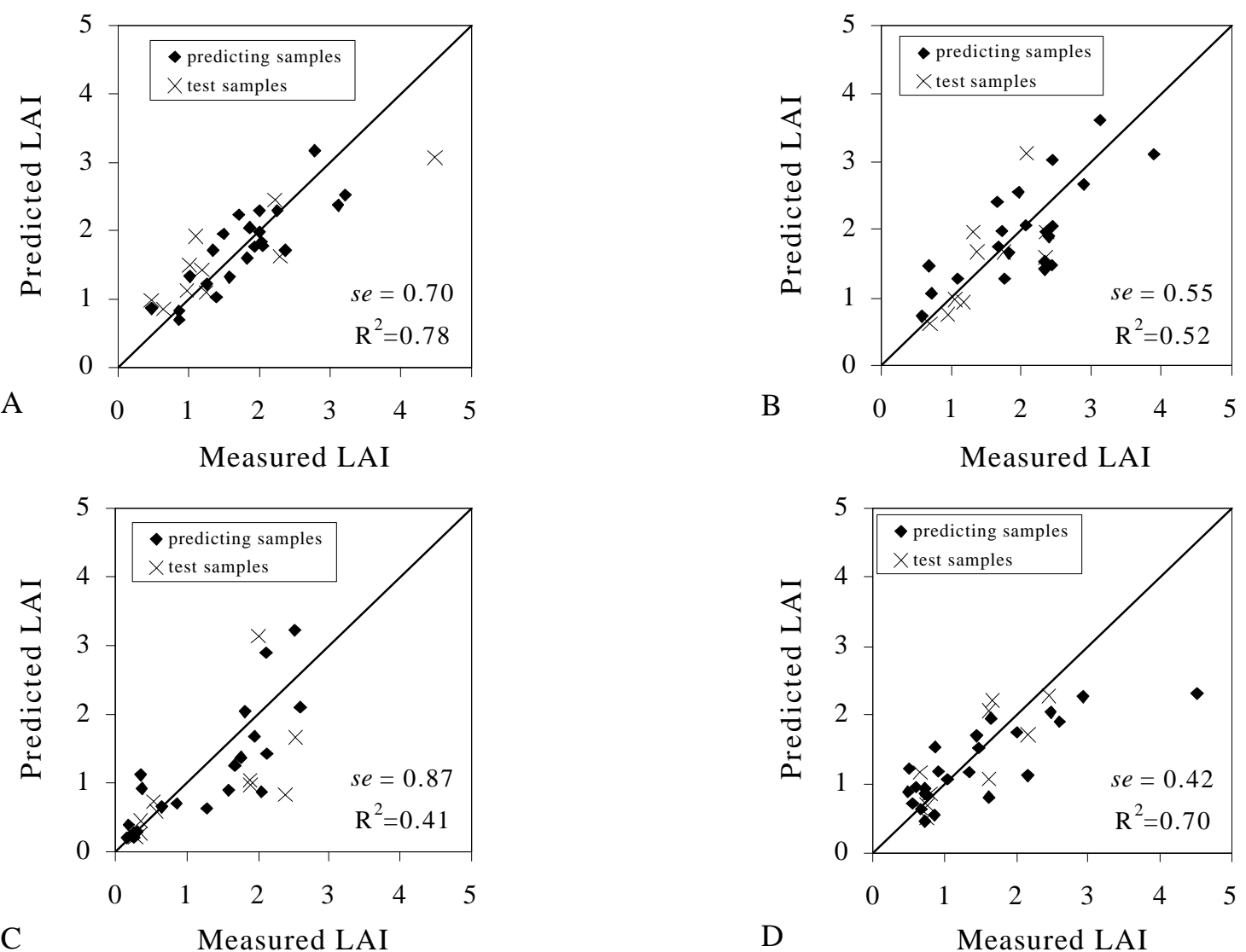

Figure 7 - Measured Leaf Area Indices compared to predicted Leaf Area Indices using potential models (Table 4) for January (a); March (b); August (c); and November (d).

Table 5 - Descriptive statistics of predicted Leaf Area Indices in the watershed, obtained by Leaf Area Index-Normalized Difference Vegetation Index relationship.

\begin{tabular}{lcccc}
\hline & January & March & August & November \\
\hline Figure & $8 \mathrm{a}$ & $8 \mathrm{~b}$ & $8 \mathrm{c}$ & $8 \mathrm{~d}$ \\
Mean & 1.59 & 1.59 & 0.97 & 1.28 \\
Median & 1.65 & 1.65 & 0.85 & 1.30 \\
Standard deviation & 0.89 & 0.83 & 0.70 & 0.66 \\
Maximum value & 4.20 & 4.20 & 4.60 & 3.00 \\
\hline
\end{tabular}

both months, the sugar cane area presented similar LAI values due to advanced development of this crop (Xavier \& Vettorazzi, 2003).

LAI estimated in the watershed by LAI-NDVI models presented some areas with either higher or lower LAI values than those measured in the field campaign. For March and August, the maximum predicted LAI were 4.20 and 4.60, respectively, while maximum measured LAI were 3.90 and 2.59. However, the area with greater predicted LAI values than those measured in the field campaign was small $(<3 \%$ of the total area). Those areas with greater LAI values corresponded to riparian forest. On the other hand, maximum predicted LAI values for January and November were lower than those measured in the field, probably because of few high LAI values measured in the field were used in the coefficient esti- mation to establish the prediction equations. It could cause bias on the respective prediction models. Areas with predicted LAI values lower than those measured in field campaign were higher, respectively $14 \%, 15 \%, 10 \%$, and $13 \%$ of the total area for January, March, August, and November. Those areas often corresponded to bare soil, sugar cane and pasture with low phytomass. In future studies, those areas should be evaluated, as well as a larger number of data with high and low LAI values should be measured to lessen models bias.

\section{Monthly LAI estimation}

LAI variability in the studied watershed presented high dynamics in relation to meteorological factors (e.g. precipitation and temperature) and to land cover types, in this case represented mainly by sugar cane and pas- 
a)

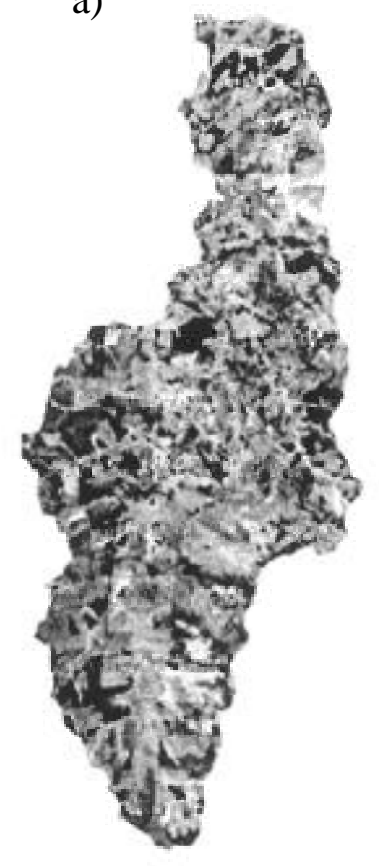

A b)

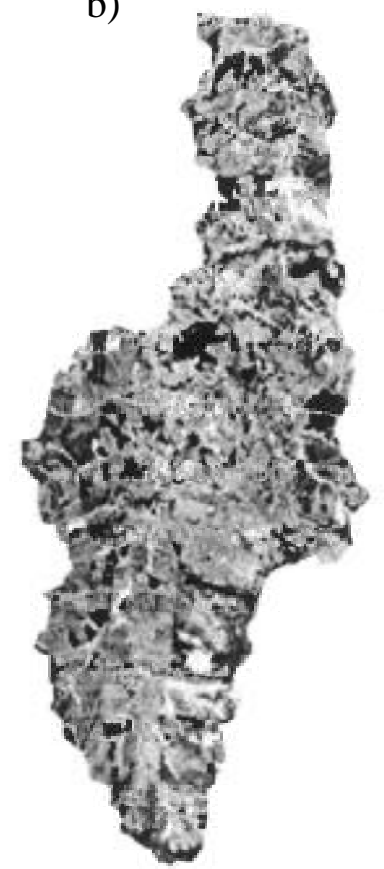

LAI

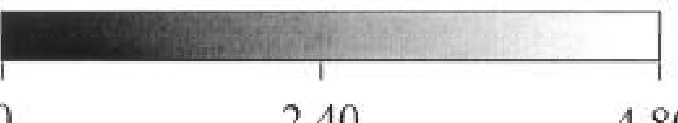

d)
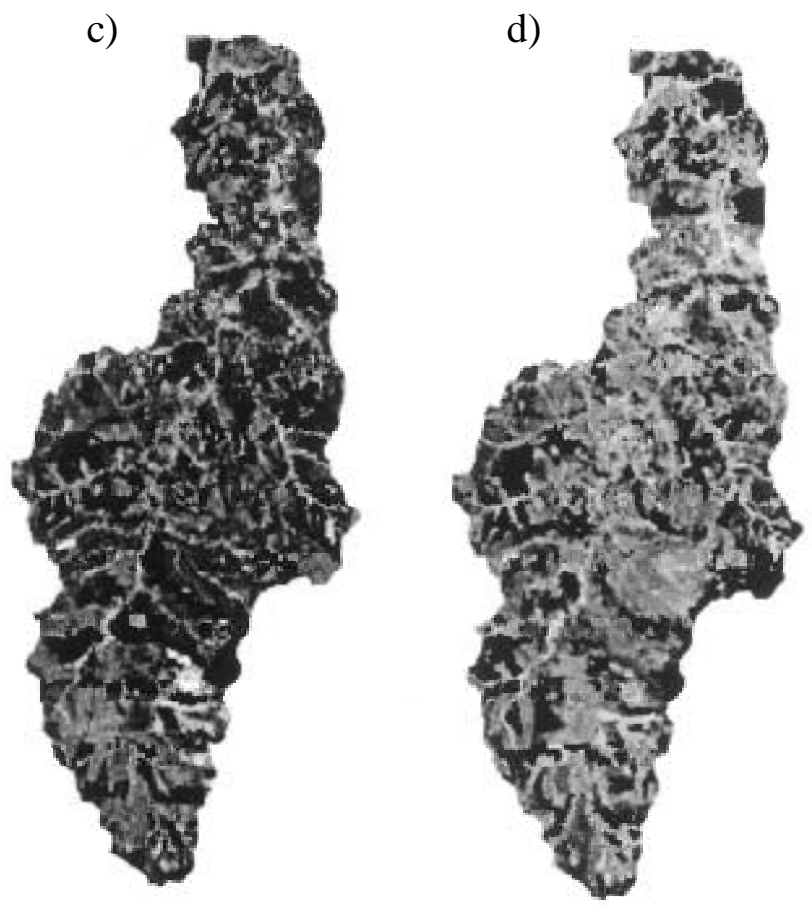

$2000 \mathrm{~m}$
0
2.40
4.80

Figure 8 - Leaf Area Index maps for the studied area, generated by relationships between Leaf Area Index (LAI) and Normalized Difference Vegetation Index (NDVI) for: January (a); March (b); August (c); and November (d).

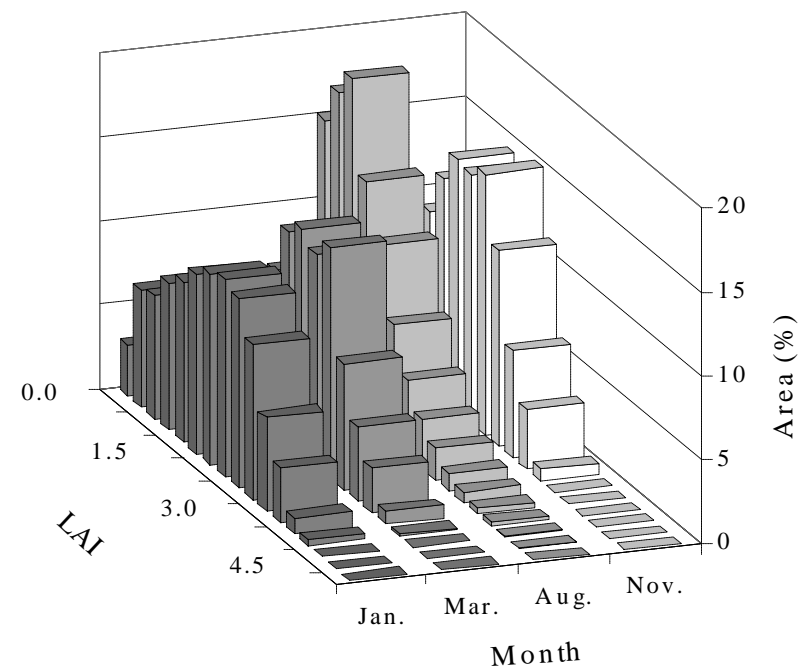

Figure 9 - Histogram of the area occupied (\%) per Leaf Area Index values in the studied watershed for January, March, August, and November.

ture, both with high seasonal dynamics. The generation of monthly LAI maps becomes a hard task without images showing the respective land covers for the considered period. Measurements of LAI in the field are also necessary to fit a regression, since NDVI values for simi- lar LAI from different dates are also influenced by background brightness and SZA. As observed in the preceding section, the mean LAI value estimated in the watershed by the relationship LAI-NDVI seems to be related to precipitation. Other studies have shown that vegetation increases with increasing precipitation (Running et al., 1989). Schmidt \& Karnieli (2002) observed, for annual vegetation, that NDVI, based in spectral ground measurements, was highly correlated (0.93) with cumulative precipitation of the previous three months.

Figure 10a shows the relationship between mean predicted LAI in the watershed for each of the four dates and total precipitation in the three previous months $\left(\mathrm{R}^{2}=0.99 ; s e=0.01 ; P<0.01\right)$. The relationships between mean predicted LAI and precipitation of one and two previous months were not significant $(P>0.05)$. Figure $10 \mathrm{~b}$ shows the monthly LAI estimate, using the model of mean predicted LAI by the total precipitation in the three previous months $\left(\mathrm{LAI}=0.2307 \mathrm{Prec}^{0.3071}\right)$. The mean monthly LAI estimated by this relationship in 2001 was 1.28 , with maximum and minimum LAI values of 1.70 and 0.94, for January and September, respectively. This is a rough estimate only since LAI-NDVI models are not $100 \%$ accurate. Moreover, it neglects the LAI dynamics of the crops and the other land covers in 

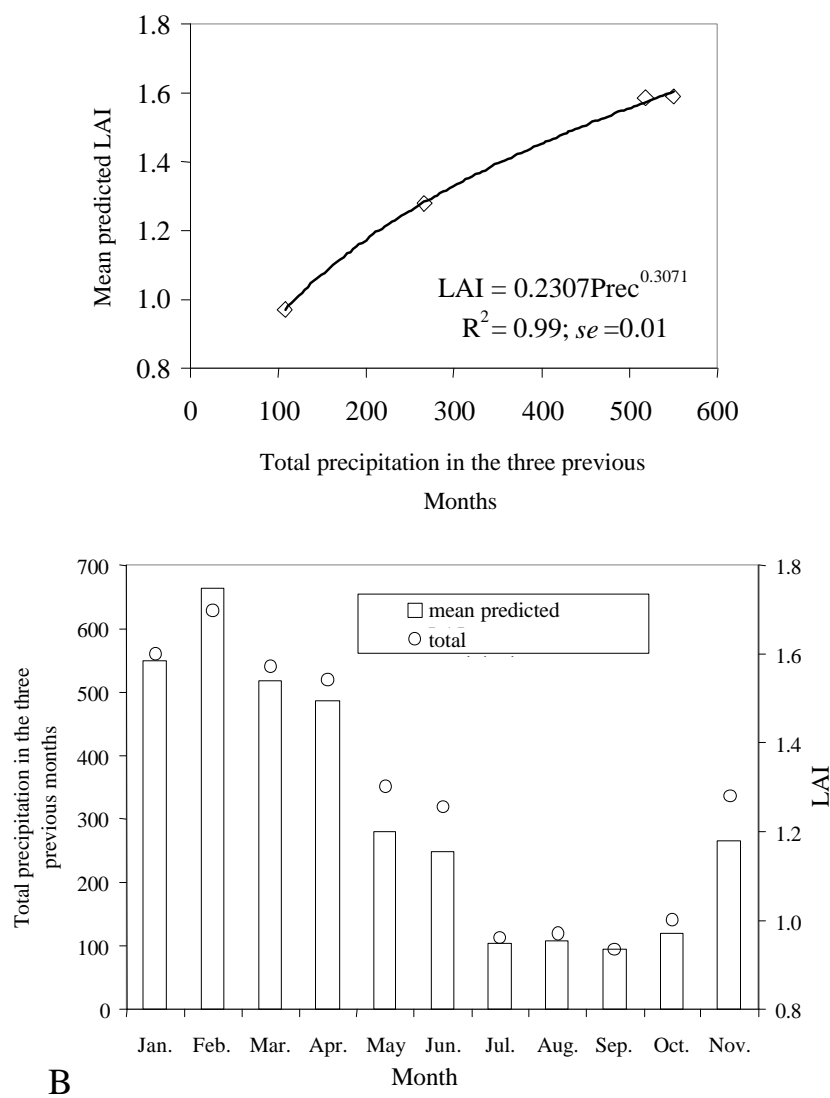

Figure 10 - Relationship between mean Leaf Area Index in the watershed (estimated by Leaf Area Index-Normalized Difference Vegetation Index relationship) and three months of accumulated precipitation (a), and monthly Leaf Area Index estimation (b).

the watershed, as for example the period of sugar cane planting and the pasture dynamics due to animal grazing. However, it seems to be a reasonable reference for the monthly LAI value in the area.

\section{CONCLUSIONS}

The NDVI, RED, and NIR responses are shown to be influenced, not only by LAI, but also by background brightness and SZA, under which each image was acquired. Eucalypt showed lower RED and NIR values, probably because of its canopy structure, with more shadows than the other land covers. As the variations in the NDVI are more sensitive to RED variations, NDVI values for eucalypt plantations often were greater than those for other land-cover types. For the range of land-cover types in this study, NDVI could be used to estimate LAI with a reasonable precision (standard error of predicted LAI estimated by means of empirical relationship with NDVI ranged from 0.42 to $0.87 \mathrm{~m}^{2} \mathrm{~m}^{-2}$ ). LAI variations were influenced by the total precipitation in the previous three months. The generation of LAI maps also makes possible the development of models to estimate regional evapotranspiration and crops yield.

\section{ACKNOWLEDGEMENTS}

To the State of São Paulo Research Foundation (FAPESP) for the financial support to this study (process 2000/09325-0) and for the fellowship for the first author (process 98/14499-5). Authors also thank Prof. Mauro A. H. Antunes, from Rio de Janeiro Federal Rural University, Brazil, for helping in the atmospheric correction with the $6 \mathrm{~S}$ model.

\section{REFERENCES}

ASRAR, G.; FUCHS, M.; KANEMASU, E.T.; HATFELD, J.L. Estimating absorbed photosynthetic radiation and leaf area index from spectral reflectance in wheat. Agronomy Journal, v.76, p.300-306, 1984.

ASRAR, G.; KANEMASU, E.T.; YOSHIDA, M. Estimates of leaf area index from spectral reflectance of wheat under different cultural practices and solar angle. Remote Sensing of Environment, v.17, p.1-11, 1985

CHEN, J.M.; CIHLAR, J. Retrieving leaf area index of boreal conifer forests using Landsat-TM images. Remote Sensing of Environment, v.55, p.153-162, 1996.

CHEN, J.M.; PAVLIC, G.; BROWN, L.; CIHLAR, J.; LEBLANE, S.G.; WHITE, H.P.; HALL, R.J.; PEDDLE, D.R.; KING, D.J.; TROFYMOW, J.A.; SWIFT, E.; VAN DER SANDER, J.; PELLIKKA, P.K.E. Derivation and validation of Canada-wide coarse-resolution leaf area index using high-resolution satellite imagery and ground measurements. Remote Sensing of Environment, v.80, p.165-184, 2002.

DEERING, D.W.; ECK, T.F.; BANERJEE, B. Characterization of the reflectance anisotropy of boreal forest canopy in spring-summer. Remote Sensing of Environment, v.67, p.205-229, 1999.

DEPARTAMENTO DE ÁGUAS E ENERGIA ELÉTRICA - DAEE. http:/ /www.daee.sp.gov.br/servicos/tabbmt.htm. (10 jan. 2002).

EPIPHANIO, J.C.N.; HUETE, A.R. Dependence of NDVI and SAVI on sun/sensor geometry and its effect on fapar relationships in alfalfa. Remote Sensing of Environment, v.51, p.351-360, 1995.

FASSNACHT, K.S.; GOWER, S.T.; MACKENZIE, M.D.; NORDHEIN, E.V.; LILLESAND, T.M. Estimating the leaf area index of north centra Wisconsin forests using the Landsat Thematic Mapper. Remote Sensing of Environment, v.61, p.229-245, 1997.

GATES, D.M.; KEEGAN, J.H.; SCHLETER, J.C.; WEIDNER, V.R Spectral properties of plants. Applied Optics, v.4, p.11-20, 1965

GOETZ, S.J. Multi-sensor analysis of NDVI, surface temperature and biophysical variables at a mixed grassland site. International Journal of Remote Sensing, v.18, p.71-94, 1997.

GONG, P.; PU, R.; MILLER, J.R. Coniferous forest leaf area index estimation along the Oregon transect using compact airborne spectrographic imager data. Photogrammetric Engineering \& Remote Sensing, v.61, p.1107-1117, 1995

GREEN, E.P.; MUMBY, P.J.; EDWARDS, A.J.; CLARK, C.D.; ELLIS A.C. Estimating leaf area index of mangroves from satellite data. Aquatic Botany, v.58, p.11-19, 1997.

HOLBEN, B.N.; TUCKER, C.J.; FAN, C.J. Spectral assessment of soybean leaf area and leaf biomass. Photogrammetric Engineering \& Remote Sensing, v.46, p.651-656, 1980

HUETE, A.R. A soil-adjusted vegetation index (SAVI). Remote Sensing of Environment, v.25, p.295-309, 1988.

JACKSON, R.B.; CARPENTER, S.R.; DAHM, C.N.; McKNIGHT, D.M.; NAIMAN, R.J.; POSTEL, S.L.; RUNNING, S.W. Water in a changing world. Ecological Applications, v.11, p.1027-1045, 2001.

JACKSON, R.D.; PINTER, P.J.; IDSO, S.B.; REGINATO, R.J. Whea spectral reflectance: interactions between crop configuration, sun elevation, and azimuth angle. Applied Optics, v.18, p.3730-3732, 1979.

JORDAN, C.F. Derivation of leaf-area index from quality of light on the forest floor. Ecology, v.50, p.663-666, 1969.

LI-COR. LAI-2000 plant canopy analyzer: Instruction manual. Nebraska: Li-Cor Inc., 1992.

MIDDLETON, E.M. Solar zenith angle effects on vegetation indices in tallgrass prairie. Remote Sensing of Environment, v.38, p.45-62, 1991 
MYNENI, B.; NEMANI, R.R.; RUNNING, S. Estimation of global leaf area index and absorbed PAR using radiative transfer models. IEEE Transactions on Geoscience and Remote Sensing, v.35, p.1380-1393, 1997.

OLIVEIRA, J.B. Solos da folha de Piracicaba. Campinas: Instituto Agronômico, 1999. 173p. (Boletim Científico, 48).

PETERSON, D.L.; SPANNER, M.A.; RUNNING, S.W.; TEUBER, K.B. Relationship of Thematic Mapper simulator data to leaf area index of temperate coniferous forests. Remote Sensing of Environment, v.22, p.323-341, 1987.

PUREVDORJ, Ts.; TATEISHI, R.; ISHIYAMA, T.; HONDA, Y. Relationships between percent vegetation cover and vegetation indices. International Journal of Remote Sensing, v.19, p.3519-3535, 1998.

ROSENBERG, N.J.; BLAD, B.L.; VERMA, S.B. Microclimate: The biological environment. New York: John Wiley \& Sons, 1983. 459p.

RUNNING, S.W.; NEMANI, R.R.; PETERSON, D.L.; BAND, L.E.; POTTS, D.F.; PIERCE, L.L.; SPANNER, M.A. Mapping regional forest evapotranspiration and photosynthesis by coupling satellite data with ecosystem simulation. Ecology, v.70, p.1090-1101, 1989.

SCHMIDT, H.; KARNIELI, A. Analysis of the temporal and spatial vegetation patterns in a semi-arid environment observed by NOAAAVHRR imagery and spectral ground measurements. International Journal of Remote Sensing, v.23, p.3971-3990, 2002.

SELLERS, P.J.; DICKINSON, R.E.; RANDALL, D.A.; BETTS, A.K.; HALL, F.G.; BERRY, J.A.; COLLATZ, G.J.; DENNING, A.S.; MOONEY, H.A.; NOBRE, C.A.; SATO, N.; FIELD, C.B.; HENDERSON-SELLERS, A. Modeling the exchanges of energy, water, and carbon between continents and the atmosphere. Science, v.275, p.502-509, 1997.

SENTELHAS, P.C.; MARIN, F.R.; PEREIRA, A.R.; ANGELOCCI, L.R.; VILLA NOVA, N.A.; BARBIERI, V. Análise dos dados climáticos e do balanço hídrico climatológico de Piracicaba. Piracicaba: DFM, ESALQ, USP, 1998. 81p.
SPANNER, M.A.; PIERCE, L.L.; PETERSON, D.L.; RUNNING, S.W. Remote sensing of temperate coniferous forest leaf area index: the influence of canopy closure, understory vegetation, and background reflectance. Remote Sensing of Environment, v.33, p.97-112, 1990.

TUCKER, C.J. Red and photographic infrared linear combinations for monitoring vegetation. Remote Sensing of Environment, v.8, p.127$150,1979$.

TURNER, D.P.; COHEN, W.B.; KENNEDY, R.E.; FASSNACHT, K.S.; BRIGGS, J.M. Relationships between leaf area index and Landsat TM Spectral Vegetation Indices across three temperate zone sites. Remote Sensing of Environment, v.70, p.52-68, 1999.

VERMOTE, E.F.; TANRÉ, D.; DEUZÉ, J.L.; HERMAN, M.; MORCRETTE, J.J. Second simulation of the satellite signal in the solar spectrum, 6S: An overview. IEEE Transactions on Geoscience and Remote Sensing, v.35, p.675-686, 1997.

VÖRÖSMARTY, C.J.; GREEN, P.; SALISBURY, J.; LAMMERS, R.B. Global water resources: vulnerability from climate change and population growth. Science, v.289, p.284-288, 2000.

WALTER-SHEA, E.A.; PRIVETTE, J.; CORNELL, D.; MESARCH, M.A.; HAYS, C.J. Relations between directional spectral vegetation indices and leaf area and absorbed radiation in alfalfa. Remote Sensing of Environment, v.61, p.162-177, 1997.

XAVIER, A.C.; VETTORAZZI, C.A. Mapping leaf area index through spectral vegetation indices in a subtropical watershed. International Journal of Remote Sensing, v.25, p. 1661-1672, 2004.

XAVIER, A.C.; VETTORAZZI, C.A. Leaf area index of different ground covers in a subtropical watershed. Scientia Agricola, v.60, p.425-431, 2003.

Received August 28, 2003

Accepted March 15, 2004 